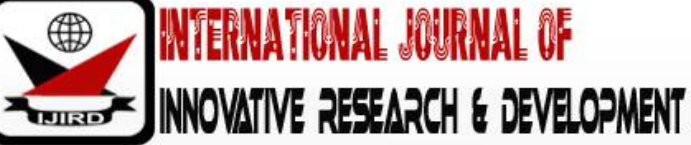

ISSN 2278 - 0211 (Online)

\section{Psychological Empowerment of Middle Level Managers and its Bearing on Human Resource Stability in Three and Five Star Hotels in Nairobi County, Kenya}

Symon Nyamu Muthigani
M. SC Candidate, Department of Hospitality and Tourism Management,
Kenya Methodist University, Kenya
Thomas Anyanje Senaji
Professor, School of Business and Economics, Kenya Methodist University, Kenya
Monica Nguta Rugongo
Chair, Department of Hospitality and Tourism management, Kenya Methodist University, Kenya

\begin{abstract}
:
The purpose of this study was to determine the effects of middle level manager's psychological empowerment on human resource stability in three and five star hotels in Nairobi County, Kenya. The main objective was to investigate the impacts of the four dimensions of psychological empowerment (Meaning, Competence, Self-determination and Impact) as experienced by middle level managers on human resource stability in three and five star hotels. The study employed a descriptive survey research design, and used quantitative methods in data collection. Convenience sampling was used to select 82 middle level operations managers, out of which 67 respondents (81.7\%) responded. Questionnaires with closed ended statements based on 5-point Likert scale were used to collect data. Descriptive statistics and inferential statistics were used to analyze data using SPSS version 22 software. The findings of the study are that psychological empowerment has a significant and positive effect on human resource stability, and each dimension of psychological empowerment significantly influenced human resource stability todiverse extents. Among the dimensions, Meaning and Impact had the most significant and positive influence on human resource stability. Both competence and self-determination had insignificant but positive influence. Results also indicated. Further, human resource stability in all the surveyed hotels was low. While majority of the respondents agreed that they had meaning in their jobs and organizations, majority disagreed that they had sufficient impact in their organizations, leading to the conclusion that lack of impact among middle level managers had caused the low level of human resource stability. It is recommended that top managements of three and five star hotels actively engage their middle level managers, communicate the vision, mission, and performance information and reward performance to enhance the feeling of impact among this vital cadre in management to improve human resource stability.
\end{abstract}

Keywords: Psychological empowerment, human resource stability, star-rated hotels, Kenya

\section{Introduction}

The global business environment is becoming increasingly intense, increasing demands for high-end accommodation and services. In the process, third world countries with their capital cities like Nairobi have been sapped into this web of high-quality demands for hospitality services from a more than ever discerning customer. To meet these strenuous demands, retention of highly talented middle management employees is crucial to the success of hospitality organizations like three and five star hotels. Middle level managers operate at a very critical point in management echelons. They are the implementers of company mission and strategies down to the front office and back office operating staff as well as actuators of empowerment programs down to the general staff. They are therefore, a critical cog to hospitality organization's competitive advantage. It is argued that, retaining and maintaining stability of highly talented middle level managers among other employees is the leading indicator of whether a business is going up or down (Conaty \& Sharon, 2013). Further arguments to this end narrow down to hospitality establishments. For instance, Dimension International (DDI) (2012) emphasizes that, in the intensely competitive and intricate global economy, hotels must motivate and retain their best talents to survive the ever up-surging competition.

Highly effective motivational programs are those that affect positively on the mental state of the employee to feel attached and committed to an organization (Psychological empowerment). Across industries in Kenya, hospitality included, management retention challenges continue unabated with only $32 \%$ retention rates in three and five star hotels (Wanderi \& Odigi, 2011) which is below the industrial optimum of 75 - 80\% (Bryant, J. 2018). In a report released on Kenya human resource capital trends 2014, Deloitte, (2014) confirms this by citing retention and engagement as the most urgent human resource trends to address with the largest capacity gap of $-28 \%$. While this was the case, the report goes 
further to revel that, only $13 \%$ of top company executives say they do an excellent job in developing and retaining staff at all levels including middle management, implying that little effort is being applied to assess the felt empowerment levels and promote human resource stability. Like in Kuria \& Odigi (2011), a research by the ILO (2010) on labor mobility in Kenya's hotels indicated a similar trend of high labor turnover and corresponding low retention levels, but this time in Lodges. However, both studies did not focus on the underlying motivational reasons (psychological motivation) behind the low retention rates, which undermine job stability.

Despite the obtaining retention capability gap and the continuing low retention rates, the three and five star hotels bed capacity is set to increase. In a report on Hotels Outlook for Kenya, PWC, (2016) observes that, international hospitality flagship companies such as Marriott, Sheraton, Ramada and Hilton Inn are planning hotels in Kenya in the next five years, adding 2,900 rooms and expanding hotel capacity by $14 \%$. This additional capacity will mean more competition to the existing hotels and may exert farther strain on the shrinking human resource stability across the spectrum.

The scenario points to an industry in perpetual struggle to psychologically empower managers to motivate optimum talent retention and maintain human resource stability at middle management level. This is an empowerment challenge that any top manager cannot ignore if an organization was to be competitive and survive in the intricate service business.

For a country like Kenya whose GDP heavily depends on tourism for export earnings (Ksh. 84.6 Billion in 2015 according to KNBS), retention of talents at middle management level hence, human resource stability is an imperative if the destination has to remain competitive in attracting the ever-discerning global customer.Studies on the effects of psychological empowerment of middle level managers on human resource stability are still scarce yet the problem of low retention levels in three and five star hotels in Nairobi County persists. For this reason, the study sought to address this problem.

\section{Literature Review}

Psychological empowerment approach to empowerment is predicated on enabling employees rather than the normative approach of transferring power to them (Spreitzer, G.M., 1995). It focuses on the motivational constructs choreographed to enhance personal competence, and facilitating employee's sense of meaning and control or impact (Thomas \& Velthouse, 1990). Power and control which are an embodiment of one's locus of control are conceptualized as motivational states that are internal to the individual (Thomas \& Velthouse, 1990) which just waits to be stimulated and activated.

Various studies have defined psychological empowerment as intrinsic task motivation (Conger \& Kanungo, 1998; Thomas \& Velthouse, 1990; Stander \& de Klerk, 2014). Spritzer, (1996) and Spreitzer \& Mishra, (1999) goes further to define psychological empowerment as increased intrinsic task motivation manifested in a set of four cognitions reflecting an individual's orientation to his/ her work; namely, meaning, competence, self-determination and impact. This sets out the difference between psychological empowerment and structural or relational domain of empowerment, which mainly focuses on management and involves changes in structural conditions through power sharing and decision-making authority (Kanter, 1993). However, Stander \& de Klerk (2014) argues that, while structural or relational forms of empowerment lays the framework of institutional motivational programs, the extent to which their impacts are felt depends on the final psychological state of the employee, hence psychological empowerment. Iftikir et al, (2016) and Pelit et al, (2011) confirms this notion with an argument that, motivational or psychological perspective of empowerment focuses on the employee's intrinsic motivation and lays emphasis on an employee's subjective commentaries of organizational environments.

Stander, Nel \& Latif, (2016) posits that, psychological empowerment increases mental stability, concentration, initiative and resilience, thus heightening managerial effectiveness and human resource stability. It follows then that, when middle level managers feel empowered in the sense that they see the meaning of their responsibilities and company, they feel capacitated and competent enough to provide leadership and inspiration. If they are given latitude to make choices in their leadership functions, they readily cascade the same empowerment contexts down to their operating staff. The sweet consequence is a stable workforce where retention intentions are increased, organizational commitment comes along and retention and competitiveness are achieved. While commitment to one's job increases retention intentions, and subsequently retention, competitiveness is borne out of HR stability over time.

Based on Spreitzer (1995) theoretical framework, psychological empowerment has four dimensions: Meaning, Competence, Self-determination and impact. The conceptualized relationship between psychological empowerment and human resource stability (job stability) is set out in Figure 1. 


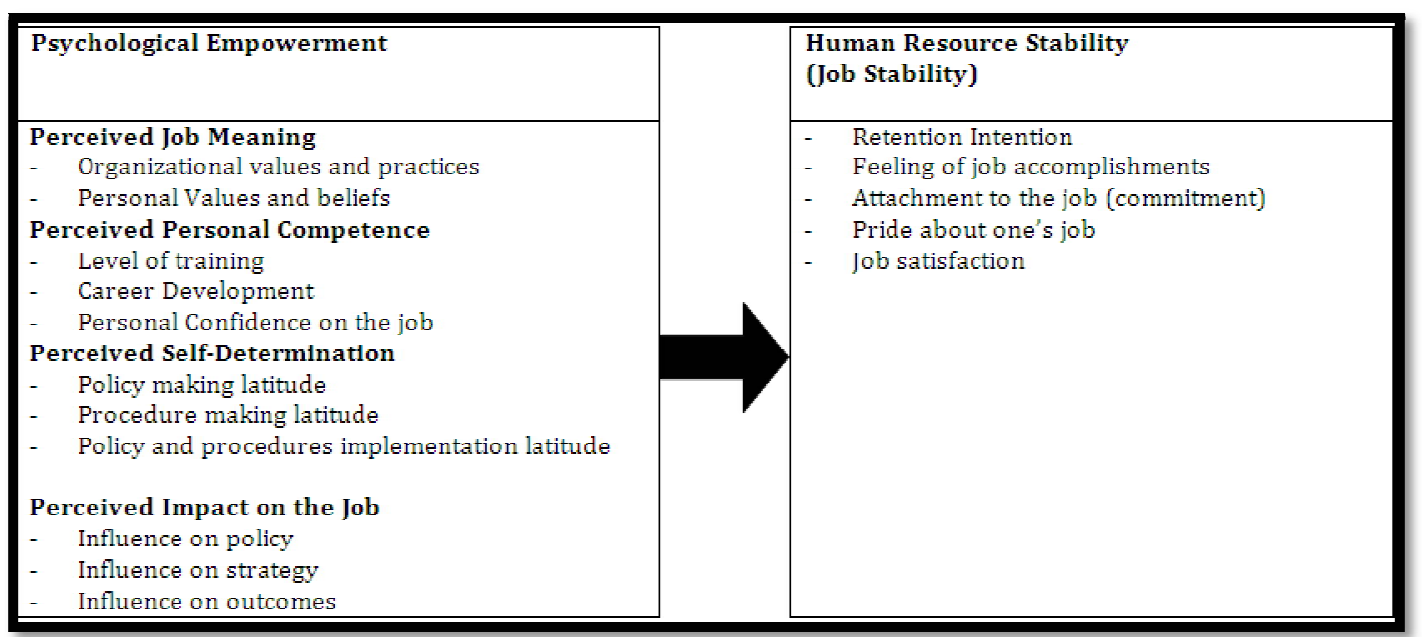

Figure 1: Conceptualization

\subsection{Job Meaning and Job Stability}

Meaning is a dimension of job characteristics model involving a "fit" between the requirements of one's work and one's beliefs, values and behavior. (Thomas \& Velthouse, 1990, cited in Iftikir et al, 2015) posits that, meaning serves as the "engine" of empowerment (i.e. the mechanism through which individuals are energized about work). If employee's hearts are not in their work, if work activity conflicts with their value system, then they will not feel empowered and will have low retention intentions, which will undermine their stability on the job. An important precondition to work is the degree to which an individual find work personally meaningful. Low levels of meaning have been linked to apathy at work and hence low levels of job satisfaction, organizational commitment and eventual tension to turnover, further contributing to low human resource stability. This applies to middle level managers as it does to all other employees. Organizations therefore, will need to provide operational and communicational contexts, which are in consonance with employee's value systems to motivate empowerment in their employees.

In imperial studies, Ikechuku and Thandokazi, (2017) posits that, job satisfaction results from the perception that one's work fulfils or allows the fulfillment of one's desired work values. Such value fulfillment is in consonance with the meaning dimension of empowerment and it fortifies job "embeddedness" to create retention intention contexts (job stability). However, personal values and beliefs are unique to the person; therefore, there cannot be a group general quick fix. Managers need to engage employees at personal level to understand their values. Unchallenging, monotonous work without meaning can be stressful to a transformative leader that middle level managers should be, while high job demands combined with low decision latitude can also be stressful to the same leader. Therefore, through active engagement, a perfect fix must be sought to energize the leader. More specifically, managers who see their jobs as personally meaningful are likely to be more personally invested and embedded in their work roles, resulting in more stability on the job.

Pratt and Ashforth, (2003) cited in Kabare, Mina and Gachunga, (2016) postulates that, individual employees must have a belief in their sense of judgment, values, work roles and behavior in connection to work, or employees must have an opportunity to be guided by their own ideals and standards to evaluate the achievement of the organizational goals or purpose.

In empirical studies, meaning has received strong support as being positively associated with organizational commitment, organizational citizenship behavior, work engagement and job satisfaction, which are all requisites for job stability (Theron, 2010; Stander, Nel \& Latif, 2015; Stander \& van Zyl, 2015). In a research conducted on the influence of psychological empowerment on organizational commitment in Kenya civil service, Kabare, Maina \& Gachunga, (2016) found that, the meaning cognition has a positive influence on organizational commitment. They recommended that, organizations have made sure that, the objectives of the work assigned tasks is compatible with employees' value system in order to be perceived as meaningful to ensure that employees are motivated and committed to the organization and stay on. However, this research was conducted in the civil service, and it involved all staff. Further still, the study only referred generally to stability on the job as orchestrated by staff commitment.

From the imperial studies on various factors of human resource stability, there is a consensus that, it is only when the "fit" between individual ideals and standards, and organizational values and practice exists that the employee will feel attached to the job and promotes human resource stability.

\subsection{Personal Competence and Job Stability}

Competence or self-efficacy is defined as is an individual's belief in his or her capability to perform responsibilities, activities or skills (Spreitzer, 1995). Competence reflects an individual's beliefs that they have what it takes to do their jobs well (Spreitzer \& Mishra. 1989). Without a sense of confidence in their capabilities, individuals feel inadequate, and they will lack a sense of empowerment (Stander, Nel \& Latif, 2015). According to Bandura, (1989), cited in Pelit et al., (2011) competence is analogous to agency belief, personal mastery or effort performance expectancy. Numerous imperial studies have found that competence has a positive relationship with job satisfaction (Ambad \&Bahron, 2012, p.74; Fong \& Snape, 2015, p.129; Ramos \& Ales, 2014). In examining the relationship between the four dimensions of psychological empowerment and job satisfaction, Ambad \& Bahron, (2012), found that, competence has a positive 
influence on the individual's propensity to like their jobs and stay on. This means that, competent feeling employees are more likely to be satisfied with their jobs compared with less competent feeling employees, and are more likely to stay on the job and perform better. Conversely, Ramos \& Ales, (2014) argues that, those managers who have low self-efficacy or competencies will tend to avoid situations that require relevant skills and will not derive satisfaction from their jobs. In essence, they live in perpetual crisis of competence and are not stable in their jobs. In examining the impacts of competence on propensity to turnover in Malaysian hotels, Ambad \& Bahron, (2012) concluded that, perception of incompetence on the job led to low job commitment and eventual turnover. Conversely, they observed that, a feeling of competency promoted commitment thereby, reinforcing job stability and reducing propensity to turnover. Commitment is a sense of duty and obligation to one's organization, which is reinforced by competence. However, effective commitment will be mostly influenced by work experience variables. Stander \& de Klerk, (2014) argues that, an important work experience variable is the leadership behavior of the middle level or line managers. Since middle level managers act as organizational representative, the extent to which they value their subordinate's contribution and care for their wellbeing will also be reflected by their competence, and will also be partly seen as an organizational accomplishment or lack of it. Spreitzer, De Janasz, \& Quinn, (1999) postulates that, competent leaders are effective leaders; they are upwards influencing, innovative and downwards inspiring. This supports Krishna, (2007) as cited by Stander \& van zyl, (2015) postulation that, since relation-oriented leadership behavior, which enhances competence building implies the friendly and supportive work environment for employees, there is reasonable argument that, it will be conceived as an effective sign of organizational commitment which will have positive impact on employee's effective job stability. This in turn reinforces human resource stability across the board. It is therefore reasonable to argue that, the feeling of competence reinforces job satisfaction, commitment to duty and organization and job stability.

\subsection{Self-Determination and Job Stability}

Self-determination is defined as the degree to which people endorse their actions at the highest level of reflection, and engage in the action with a full sense of choice (Spreitzer, De Janasz \& Quinn, 1999; Stander \& de Klerk, 2014). According to Spreitzer, (1995), self-determination refers to an individual's sense of control and autonomy, and observes that, its absence in a work context makes employees feel helpless because they are not allowed to take work-related actions that they deem appropriate. Therefore, all these definitions imply that the feeling of choice or having freedom to choose, that is being able to exercise one's own judgment of how the task should be executed.

Due to the strategic impact that middle level managers have in the hospitality industry, it is imperative that, senior management understands how self-determination as a dimension of psychological empowerment shapes middle level managers attitudes towards their jobs so as to secure their stability on the job. It is generally agreed that, hotel workforce has a high level of temporary workers (Davidson, Timo, Nils, Wang \& Ying, 2010), and low levels of training that define high employee turnover rate which is a threat to human resource stability. This situation begs that, middle level managers should have adequate self-determination to continuously deal with the threat.

Several imperial studies have shown that, there is a positive relationship between self-determination, and job satisfaction and commitment which in turn translate to stability on the job and talent retention (Spreitzer, De Janasz \& Quinn, 1999; Buitendach \& Hlalele, 2015; Das \& Baruah, 2013; Stander, Nel \& Latif, 2015; Kabare et al, 2016). In a study on the role psychological empowerment in leadership, Spreitzer, De Janasz \& Quinn, (1999) found that, there is a significant and positive relationship between self-determination and job satisfaction. This implies that, when a manager is given decision-making latitude, communication latitude and the freedom to decide on operational strategies, he or she gets a boost of confidence, self-esteem is enhanced and gets stable on the job. This notion is further confirmed by Parker \& Price (1994) as cited in Buitendach and Hlalele, (2015) by clarification that, self-determination seems to boost confidence, making tasks less stressful and more intrinsically worthwhile. They also posit that, confidence, job satisfaction enhances job stability, and increases retention intentions thus, job stability. Das \& Baruah, (2013) focuses on involvement and communication thus; at a reasonable level of communication, employees feel involved in organizational decisions and are clear about the organization's strategic direction. Moreover, they argue that; if middle level managers and other employees are involved well in the organization's decisions, it will help in creating a sense of belonging, which will in turn create a good working environment. This will also create good relations in the workplace and stability. Lack of communication (communication latitude) leaves employees feeling disconnected from the organization, and lacks confidence and selfdetermination, which can make them, leave the organization easily. De Klerk \& Stander, (2014) focuses on decisionmaking latitude. They argue that, empowerment exists when managers perceive they exercise some control over their work-life, which has a great potential in contributing towards achieving organizational objectives and stability. They further juxtapose that with communication latitude by observing that, antecedent to this dimension is obviating extreme bureaucracy in the work place by allowing managers to make decisions and contribute to policies to reinforce manager's self-esteem and locus of control, and supporting managers through sharing of information critical to policies and procedures. Nawawi et al., (2015) concluded that, there exists a positive relationship between employee's selfdetermination and retention intentions.

Self-determination builds commitment among staff to promote stability. It makes managers feel they belong as they can practice their decision-making skills without undue interference particularly in adverse conditions. In their study on the effect of psychological empowerment on employee's commitment, Kabare et al., (2016) concludes that, when selfdetermination is offered to employees, they can complete their work more effectively. As such, self-determination can enable individuals be more interested in their work and be more optimistic even when difficulties arise, cushioning against propensity to turnover. 
The reviewed literature clearly demonstrates a positive relationship between self-determination and middle level manager's job stability.

\subsection{Impact and Job Stability}

Impact is defined as the degree to which an individual can influence strategic, administrative and operating outcomes of work (Ashforth, 1989). However, (Spreitzer, 1995) takes the behavioral aspect and defines it as the degree to which behavior is seen to make a difference in terms of accomplishing the purpose of the task that is producing the intended effects in an individual's task environment. Borrowing from Ashforth's definition, Van Eden (2010) postulates that, if middle level managers like any other employees believe that they can make an impact on the system they are rooted in, and that, they can influence organizational strategies and outcomes, they feel effective and are motivated to stay on. A study conducted by the researcher found impact to be associated with an absence of withdrawal from difficult situations and high performance. Withdrawal from difficult situations is often a precursor to turnover intentions and it negatively affects retention of talents and job stability. According to Renshon, (1979) as cited in Stander \& Van Zyl, (2015), any manager has the need to have influence over people, events and organizational decisions, that is, a need for personal control. This implies that, if that need is withdrawn, the manager develops apathy towards work and develops propensity to turnover because of deflated self-esteem. This notion is further confirmed by Fourie and Van Eden (2010, p. 23) where they proffer that, "when a person has developed the belief that he/ she has personal control, there is also the belief that they have impact".

The effects of impact dimension on commitment to one's job is far reaching, yet it can be so latent that top management may not notice if it's not carefully evaluated and provided for. This was demonstrated by Kab are et al., (2016) while assessing the role of psychological empowerment dimensions on commitment of Kenya's civil service employees. They found that employees disagreed that they had opportunities to give opinions and suggestions, were able to influence organizational strategies, and administrative or operating outcomes, yet, they agreed that they could do better and stay on if they had significant influence in their organizations. The study concluded that, employees in Kenya's public sector lacked impact cognition, which negatively influenced commitment to their organizations and led to exodus from civil service to the private sector. This underscores the effects the impact cognition has on job stability and the overall human resource stability and the overall human resource stability in formal organizations. However, the study did not specifically focus on middle level managers and was limited to the civil service employees. As to whether this applies to middle level managers in three and five star hotels in Nairobi, it is the purpose of this study.

\section{Methodology}

In this section we discuss the research design, study variables, location of the study, target population, sampling procedure, instrumentation and pre-testing of instruments, data collection procedure, data analysis and data presentation techniques that were used in the study; and finally, the logistical and ethical considerations that were applied.

A descriptive research design was used whereby the characteristics of various variables studied were analyzed, described and relationships established.

\subsection{Target Population and Sample}

The target population of this study was all operations middle level managers comprising departmental managers and senior supervisors in three- and five-star hotels in Nairobi County, Kenya. As asserted by Gay (1976) a sample should be able to reflect the population characteristics. In this regard convenience sampling technique was used to select the population of study which consisted of 25 departmental managers and 57 senior supervisors in operational departments as the study respondents in five hotels. Since the number of target population was small, a census survey of all the 82 managers in three and five hotels which comprised middle level managers using questionnaires which were selfadministered.

\subsection{Instrumentation}

A preformatted written set of statements were prepared to which respondents recorded responses within defined alternatives. The questionnaires had pre-coded responses on a five-point Likert scale. Questionnaires were chosen because they required minimal resources in terms of time, human resource and cost to cover the sample. Closed ended statements based on the 5-point Likert scale were Strongly disagree $=1$, disagree $=2$, somewhat agree $=3$, agree, and strongly agree $=5$ were used to collect data. The respondents were requested to record answers within those closely defined alternatives. Pilot testing of the questionnaire was done and all validity and reliability determined.

Validity of instruments. In order to be certain that a valid concept was measured and not something else, the following types of validity were used. Content validity was used to ensure that a representative set of items and adequate items were included in the instruments. According to Cooper \& Schindler, (2011), the more the scale items to represent the items of the concept being measured, the greater the content validity. All the instruments and scales were found to be valid. The constructs had a Cronbach alpha of at least 0.7. The purpose of these tests was to ensure all the questions made sense and the respondents were able to understand them, and answer in a meaningful way as it was intended. Relevant corrections were then made to the questionnaire where necessary.

Reliability of Instruments. In order to establish how consistently the measuring instrument were to measure the concepts in this study without any bias or error overtime and across the various items in the instruments, Cronbach's alpha reliability test and inter-item consistency reliability were used. Inter-item consistency reliability was used to measure consistency of respondent's answers to all the items in a measure. Items of independent measures of the same 
concept were correlated with each other and reliability established across items. The Cronbach's alpha return of more than the recommended 0.7 (Spreitzer, 995) was obtained. Therefore, the instruments used in this study were found to be internally consistent (reliable).

\subsection{Data Collection}

Questionnaires were used to collect primary data as they required minimal resources in terms of time, human resource and cost, and covered an appropriate sample. Secondary data was gathered formbooks, journals, magazines, internet and various relevant reports. The psychological empowerment scale constructed by Spreitzer, (1995) was used to guide the formulation of the questionnaire to measure psychological empowerment. It is a self-evaluation questionnaire designed to measure the four dimensions of psychological empowerment as conceptualized by Thomas and Velthouse, (1990), namely, Competence, Self-determination and Impact. The instrument consisted of 20 items, 5 items for each dimension of psychological empowerment measured on a 5-point Likert scale ( $5=$ strongly agree, and $1=$ strongly disagree). Measurements of human resource stability used Mayer (1993) commitment measuring instrument as modified by Manjavacas and Iborra(2014) and Amband and Bahron (2012) to include retention intentions and job satisfaction. The tool for HR stability includes seven factors. Factors 1 and 2 measures job satisfaction, 3, 4 and 5 measures commitment and retention intentions, 6 measures communication flow and 7 measures job security. In this study, the instrument was used with some modifications to fit the objectives of this specific study. Demographic, background data, behavioral and attitudinal data were gathered using this method effectively and efficiently. Questionnaires were administered personally to the respondents to fill for collection after a few days. Out of the distributed total of 82 questionnaires, 67 were collected and authenticated, translating to a total response rate of $81.7 \%$.

\subsection{Data Analysis}

In this study, the researcher used descriptive statistics to analyze data. He used both qualitative and quantitative measures to ensure accuracy of the results. It involved assigning each response a numerical value. Since the largest percentage of the data collected was qualitative, the obtained information was systematically edited and coded. Inferential data analysis technique such as regression and factor analysis were used to analyze the collected data. Descriptive analysis such as frequencies and percentages were used to show specific relationships between variables, and the research questions in the study SPSS version 22 software was used to generate suitable tables for analysis in order to achieve logical findings, conclusions and recommendations.

\section{Results and Discussion}

The results comprise frequency distribution on demographic data, descriptive statistics and inferential statistics. We first present demographic data, descriptive results and discussions, and end with correlation and regression results.

\subsection{Demographic Characteristics}

Data on gender was collected and analyzed and the results presented in table 1 below

\begin{tabular}{|c|c|c|c|}
\hline & & Frequency & Percent \\
\hline Valid & Female & 25 & 37.3 \\
\hline & Male & 42 & 62.7 \\
\hline & Total & 67 & 100 \\
\hline
\end{tabular}

Table 1: Gender

More responses were received from the males (62.7\%) compared to female managers (37.3\%). This implies that there were more male than female middle level managers in the hotels that were studied.

\subsection{Marital Status of Respondents}

Data was collected on marital status and analyzed. Results of the analysis of data on marital status are presented in table 2 below

\begin{tabular}{|c|c|c|c|}
\hline & & Frequency & Percent \\
\hline Valid & Married & 42 & 62.7 \\
\hline & Single & 25 & 37.3 \\
\hline & Total & 67 & 100 \\
\hline
\end{tabular}

Most of the respondents were married (62.7\%). Compared to their ages and positions, it is expected that most of them would be married. The unmarried ones could belong to the younger category who are yet to settle down.

\subsection{Star Rating of Hotels}

Data on star rating on returns per star rating of hotels were collected and presented in Table 3. 


\begin{tabular}{|c|c|c|c|}
\hline & & Frequency & Percent \\
\hline Valid & 3-star hotels & 39 & 58.2 \\
\hline & 5-star hotels & 28 & 41.8 \\
\hline & Total & 67 & 100 \\
\hline
\end{tabular}

Table 3: Star Rating of Hotels

The respondents belonged to 3-star and 5- star hotels. The majority (58.2\%) being from 3-statr hotels while the rest (41.8\%) were from 5- star hotels. Though three hotels were chosen from each rating, one 5-star hotel declined to participate in the studies citing "company policy not to participate in external research studies". This explains the skewed distribution of the responses

\subsection{HR Stability}

Descriptive results on HR stability are presented in Table 4.

\begin{tabular}{|c|c|c|c|c|c|c|}
\hline & Aspects & $\mathbf{N}$ & Min & Max & Mean & Std. Deviation \\
\hline STA1 & I get a feeling of accomplishment from my job. & 66 & 2 & 5 & 3.92 & 0.882 \\
\hline STA2 & $\begin{array}{c}\text { At the end of each working day, I feel that the } \\
\text { day has been well spent. }\end{array}$ & 66 & 1 & 5 & 3.77 & 0.908 \\
\hline STA3 & $\begin{array}{c}\text { If I were between careers, I would choose this } \\
\text { job. }\end{array}$ & 66 & 1 & 5 & 3.36 & 1.223 \\
\hline STA4 & $\begin{array}{c}\text { If other people can get a job like mine, they } \\
\text { would be very lucky. }\end{array}$ & 66 & 1 & 5 & 3.24 & 1.203 \\
\hline STA5 & I am satisfied with and committed to my job. & 66 & 1 & 5 & 3.64 & 1.047 \\
\hline STA6 & $\begin{array}{c}\text { Any time I raise a grievance with the } \\
\text { management it's addressed abruptly. }\end{array}$ & 66 & 1 & 5 & 2.98 & 1.196 \\
\hline STA7 & I feel secure with my job & 66 & 1 & 5 & 3.29 & 1.262 \\
\hline & Valid N(listwise) & 66 & & & & \\
\hline
\end{tabular}

Table 4: Descriptive Results on HR Stability

The results in Table 4 shows the extent of retention intentions (extent of commitment or loyalty or wanting to remain in employment) among middle level managers in the surveyed hotels. According to the results, the aspect with the highest retention intentions score was the feeling of accomplishment from their jobs (I get a feeling of accomplishment from my job, $\mathrm{M}=3.92, \mathrm{SD}=0.882$ ) implying that, a significant majority felt that their jobs were fulfilling. This could be because their senior positions gave some self-esteem in their lives. The second highest scoring was the feeling that at the end of their working day, they felt the day has been well spent (At the end of each working day, I feel that the day has been well spent, $\mathrm{M}=3.77, \mathrm{SD}=0.908$ ). This implies that, a significant majority loved what they did on a daily basis. Most likely, they would want to remain in their current employment. The above two factors have met the threshold of optimum HR stability.

The mean responses on the other factors are as follows. First was the feeling of satisfaction and commitment to their jobs (I am satisfied and committed to my job, $\mathrm{M}=3.64, \mathrm{SD}=1.047$ ). This would imply that, although most of them agreed that they were satisfied and committed to their jobs, a significant number of them did not agree to the aspect, thus failing to meet the recommended retention intention threshold. Following that was the question of choice between the current job and another opportunity (If I were between jobs, I would choose this job) (M=3.36, SD=1.223). This aspect is a defining one in terms of retention intentions. The low score on this aspect implies that, although most of them agreed that they would choose the current job, a critical number did not agree, failing to meet the HR stability threshold. This would mean that, given the choice, a critical mass of middle level managers would leave their organizations for better opportunities elsewhere. Following that was the question of whether they feel secure in their current jobs (I feel secure with my job, $M=3.29, \mathrm{SD}=1.262$ ). The low score on this aspect implies that a critical number of them did not feel secure with their jobs. This would mean that they would leave soonest if an opportunity presents itself. This was followed by the question of whether they would consider other people lucky if they got their current jobs (If other people can get a job like mine, they would be very lucky) $(\mathrm{M}=3.24, \mathrm{SD}=1.203)$. The low score on this aspect implies that, an even bigger critical mass of middle level managers did not wish others to have their current jobs, meaning that, although they liked what they did on a daily basis, they would rather they did it elsewhere. This aspect did not meet the threshold. The least scoring aspect was the question of top management responsiveness to their grievances (Any time I raise a grievance with the management, it is addressed abruptly) $(\mathrm{M}=2.98, \mathrm{SD}=1.196)$. The very low score on this aspect indicated that, majority of middle level managers felt that their grievances were not attended to as fast as they desired if at all. This would mean that, they had substantial underlying grievances, which required attention, and this may be because of unresponsive top management behavior, which is not appropriate for promoting psychological empowerment. Accumulated grievances cause latent resistance in the workplace, and are one of the major cause's involuntary turnovers in hospitality establishments (Davidson, Timo \& Young, 2010). 
4.5. Relationship between Psychological Empowerment and Human Resource Stability

Data on the relationship between Psychological Empowerment dimensions (Meaning, Competence, Selfdetermination and Impact) and Human Resource stability (STA) were analyzed using correlation analysis and the results are presented in Table 5.

\begin{tabular}{|c|c|c|c|c|c|}
\hline & PM & PC & SD & IM & STA \\
\hline Perceived competence(PM) & & & & & \\
\hline Perceived competence(PC) & $.533^{* *}$ & & & & \\
\hline & $\varangle 0.001$ & & & & \\
\hline Self-determination(SD) & $.730^{* *}$ & $.660^{* *}$ & & & \\
\hline & $\varangle 0.001$ & $\varangle 0.001$ & & & \\
\hline Impact in department(IM) & $.773^{* *}$ & $.629^{* *}$ & $.873^{* *}$ & & \\
\hline & $\varangle 0.001$ & $\varangle 0.001$ & $\varangle 0.001$ & & \\
\hline Human resource stability(STA) & $.851^{* *}$ & $.564^{* *}$ & $.776^{* *}$ & $.838^{* *}$ & \\
\hline & $\varangle 0.001$ & $\varangle 0.001$ & $<0.001$ & $<0.001$ & \\
\hline $\mathrm{N}=66$ & & & & & \\
\hline
\end{tabular}

Table 5: Relationships between (PM, PC, SD, PI) and STA

** Correlation Is Significant at the 0.01 Level (2-Tailed)

The results in Table 5imply that, psychological empowerment is very much strongly and specifically related with Human resource stability in three and five star hotels because all correlation coefficients were above 0.5(r less than 0.5), and were specific at $p$ less 0.001 . The ratings of psychological empowerment factors were strongly correlated with human resource stability (STA) factors in PM $(r=0.851, p<0.001)$, IM $(r=0.838, p<0.001), S D(r=0.776, p<0.001), P C(r=0.564$, $\mathrm{p}<0.001$ ). Therefore, psychological empowerment factors were very strongly correlated with HR stability.

Model summary. Description statistics on the influence of PE on STA was analysed and presented in table 6 below

\begin{tabular}{|c|c|c|c|c|}
\hline Model & R & R Square & Adjusted R Square & Std. Error Of The Estimate \\
\hline 1 & $.899 \mathrm{a}$ & 0.809 & 0.796 & 0.46676 \\
\hline
\end{tabular}

Table 6: Model Summary

a. Predictors: (Constant), PM, PC, SD, IM

The results in Table 6 shows that psychological empowerment (PM, PC, SD and PC) contribute $80.9 \%$ of variation in Human resource stability, meaning that, other factors not in this study only contributed to $19.1 \%$ of variations in Human resource stability in three and five star hotels. Therefore, the model used in this study was a perfect fit.

\subsection{Significance of the Analytical Model}

Linear regression analysis was done to establish the level influence andsignificance of the dimensions of psychological empowerment (PE) dimensions on human resource stability (STA), and presented in Table 7.

\begin{tabular}{|c|c|c|c|c|c|c|}
\hline Model & & $\begin{array}{c}\text { Sum Of } \\
\text { Squares }\end{array}$ & Df & $\begin{array}{c}\text { Mean } \\
\text { Square }\end{array}$ & F & Sig.(P Value) \\
\hline 1 & Regression & 55.316 & 4 & 13.829 & 63.475 & .001 \\
\hline & Residual & 13.072 & 60 & 0.218 & & \\
\hline & Total & 68.387 & 64 & & & \\
\hline
\end{tabular}

Table 7: ANOVA (Analysis of Variances)

a. Dependent Variable: Human Resource Stability

The results of ANOVA analysis (Linear regression model) in Table 7 shows that each of the dimensions of psychological empowerment had a great and significant influence on Human resource stability albeit in diverse extents $(\mathrm{F}=63.475, \mathrm{p} \varangle 0.001)$. It also shows that, the probability that Psychological empowerment did not affect Human resource stability of middle level managers was negligible or close to nil ( $p=000)$. This conforms with Lee and Way, (2010) observations that, the four dimensions of psychological empowerment play a significant and major role in determining whether a manager wants to stay or leave an organization or employer.

\subsubsection{Relative Influence of Psychological Empowerment Factors on Human Resource Stability}

Regression coefficients are shown in Table 8 


\begin{tabular}{|c|c|c|c|c|c|}
\hline & \multicolumn{2}{|c|}{$\begin{array}{c}\text { Unstandardized } \\
\text { Coefficients }\end{array}$} & $\begin{array}{c}\text { Standardized } \\
\text { Coefficients }\end{array}$ & T & Sig.(P-Value) \\
\hline & B & Std. Error & Beta & & \\
\hline (Constant) & -1.086 & 0.544 & & -1.996 & 0.051 \\
\hline Impact (IM) & 0.391 & 0.129 & 0.386 & 3.034 & 0.004 \\
\hline Self-determination (SD) & 0.085 & 0.143 & 0.073 & 0.596 & 0.553 \\
\hline Competence (PC) & 0.03 & 0.138 & 0.016 & 0.217 & 0.829 \\
\hline Meaning (PM) & 0.717 & 0.13 & 0.493 & 5.500 & $\varangle 0.001$ \\
\hline
\end{tabular}

Table 8: Coefficient Analysis

a. Dependent Variable: Human Resource Stability (STA)

The results in Table 8 confirmed that the meaning dimension $(t=5.500, p=0.001)$ had the biggest influence on HR stability of middle level managers. Conversely, the personnel competence dimension $(t=0.217, p=0.829$ had the lowest (and insignificant) influence on HR stability of middle level managers. This is in agreement with the findings of Thomas and Velthouse (1990) as cited by Iftikar et al. (2015) that the meaning dimension serves as the "engine" of empowerment (that is, the mechanism through which individuals are energized about stability and work). If employees' hearts are not in their work, and if work activities conflict with their value systems, then they will not feel empowered and will have low retention intentions, which will undermine stability on the job. Moreover, Kabare, Maina and Gachuga (2016) confirms the same in their findings that the meaning cognition has a very positive influence on organizational commitment, which is a principal requisite factor for stability on the job.

The results also showed that, although competence dimension contributed to human resource stability, its contribution was not significant in the workplace than all the other dimensions for middle level managers. This would mean that, since most middle level managers $(86.6 \%)$ already had the requisite qualification for their positions (degrees and diplomas), qualifications and further competence building mattered less in reinforcing their stability on the job, unless they were learning new skills to improve their efficiency and effectiveness at work or for career development. This confirms Ahmed and Baron, (2012) assertion that, competent feeling employees are more likely to be satisfied with their jobs than less competent feeling employees, and are likely to stay on the job and perform better.

Closely following was the meaning dimension in terms of significant influence was the impact dimension ( $t=3.034$, $\mathrm{p}=0.004$ ), Middle level management is a leadership position and leaders love making an impact in their work to fortify their self-esteem, hence the significance influence of this dimension to HR Stability. Ashforth (1989) as cited in Van Eden, (2010) posits that, if middle level managers believe that they can make an impact in the system they are rooted in, and that they can influence organizational strategies and outcomes, they feel effective, and are motivated to stay on. The influential relevance of Impact dimension is clearly underscored by Kabare, Maina and Gachunga (2016) when they posit that, employees in Kenya public sector lacked the impact cognition which, negatively influenced commitments to their jobs and organizations, leading to exodus from the civil service to the private sector.

Although Self-determination came a distant third in terms of its influence on Human resource stability ( $\mathrm{t}=0.595$, $\mathrm{p}=0.553$ ), it still maintained a moderate influence. This would mean that, middle level managers in hotels have moderate freedom and latitude to make and influence decisions. However, it would still be better to increase the latitude to give them a sense of control and reduce some semblance of helplessness, for theirs are leadership positions. According to Spreitzer (1995), self-determination refers to an individual's sense of control and autonomy. She observed that, its absence in a work context makes them feel helpless because they do not have the latitude to make decisions where they deem appropriate. However, in organizations that are strictly structured like five-star hotels (Davidson, Timo \& Yang, 2010) this precarious balance will always be a challenge.

In summary, while Perceived Meaning (PM) and perceived impact (IM) significantly and positively influenced Human resource stability (PM: $t=5.500$, p less than 0.001; IM: $t=3.034$, $p=$ less than 0.050 ), the influence of both Perceived Self-determination SD ( $t=0.596, p=$ greater than 0.05$)$ and Perceived Competence $P C(t=0.217, p=$ greater than 0.05$)$ was not significant though positive.

Whereas some dimensions were weaker in influence than others are, the results indicate that, the presence of each one of them contributed positively to HR stability of middle level managers like siblings. Therefore, psychological empowerment context may not be complete until all of them are provided and felt in the workplace. Several empirical studies on psychological empowerment in the workplace have confirmed this (Spreitzer, 995; Spreitzer, De Janasz \& Quinn, 1999; Stander \& de Clerk, 2014; Stander \& Van Zyl, 2015; Nawawi et al., 2015). In particular, Spreitzer, De Janaz and Quinn (1999) strongly argues that, the four dimensions combine additively to create an overall construct of psychological empowerment, and the lack of any single dimension will lower though not completely eliminate, the overall degree of felt empowerment.

\subsubsection{Summary of Rating of Psychological Empowerment Dimensions Results}

The extent of presence of perceived meaning (PM) personal competence (PC), self-determination (SD), and impact (IM) were determined based on composite mean scores. The composite resultant scores of all dimensions were summarized and compared against the mean threshold measurement of 3.45 as sufficient to indicate presence of 
psychological empowerment following Spreitzer's scale (Spreitzer, 1995; see also Ambad \& Bahron, 2012). The summary is presented in Table 9.

\begin{tabular}{|c|c|c|c|c|}
\hline $\begin{array}{c}\text { Psychological } \\
\text { Empowerment } \\
\text { Dimension }\end{array}$ & $\begin{array}{c}\text { \# of factors } \\
\text { rated above } \\
\mathbf{3 . 4 5}\end{array}$ & $\begin{array}{c}\text { \# of factors } \\
\text { below 3.45 }\end{array}$ & $\begin{array}{c}\text { Factor } \\
\text { strength }\end{array}$ & Dimension significance \\
\hline Meaning & 5 & 0 & Strong & Significant and positive \\
\hline Competence & 5 & 0 & Very strong & Insignificant but positive \\
\hline Self-determination & 4 & 1 & Moderate & Insignificant but positive \\
\hline Impact & 2 & 3 & Very weak & Significant and positive \\
\hline
\end{tabular}

Table 9: Summary of Dimensional Significance and Strength of Presence

Overall, on a scale of 1-5 on the Likert scale, the competence and meaning dimensions received the highest positive perception score (All 3.45 and above) implying that most middle level managers in the surveyed hotels strongly believed that they had sufficient competence to perform their duties properly. Since an overwhelming majority (86.6\%) were diploma or degree holders, this level of confidence is to be expected. The high score on meaning implied that a large majority of middle level managers substantially agreed that, organizational values and practices were in agreement with their values and beliefs, this was followed by Self-determination (4 cored above 3.45) implying that, their organizations accords them sufficient freedom to run their departments. However, the impact dimension fared poorly, (2 above and 3 below the threshold of 3.45), implying that, middle level managers in the surveyed organizations did not sufficiently feel the impact they made in their respective organizations.

\subsubsection{Summary of Human Resource Stability (STA) (Relative Factor Score)}

Table 10 shows the strength of human resource stability as manifested from the responses on the 7 factors measure for human resource stability. The minimum threshold was set at 3.75 on a 5-pointLikert scale (Amband \&Bahron, 2012).

\begin{tabular}{|c|c|c|c|}
\hline $\begin{array}{c}\text { Max Factor } \\
\text { Tested }\end{array}$ & $\begin{array}{c}\text { \#Of Factors Above } \\
\text { Threshold }\end{array}$ & $\begin{array}{c}\text { \# Of Factors Below } \\
\text { Threshold }\end{array}$ & HRS Strength \\
\hline 7 & 2 & 5 & Low \\
\hline
\end{tabular}

Table 10: Level of Human Resource Stability (Relative Factors Core)

Table 10 shows that only 2 factors out of the 7 that were measured scored above the threshold of $(M=3.75)$, implying that, human resource stability in the surveyed three- and five-star hotels was low.

\section{Conclusion}

Results of the descriptive analysis shows that psychological empowerment (PM, PC, PSD and PI) contributed $80.9 \%$ of variation in human resource stability, and only $19.1 \%$ of the variation in human resource stability can be explained by other factors not in this study. The correlation coefficient also shows a strong relationship between psychological empowerment and human resource stability (above $0.5(r>0.5)$ and are specific at $(p<0.001)$. Therefore, the research concludes that psychological empowerment has a significant and positive influence(bearing) on Human resource stability in three- and five-star hotels. This is in agreement with empirical studies (Nawawi et al,.2015; Ambad and Bahron, 2012). The higher the Psychological empowerment of middle level managers, the higher the human resource stability becomes at that level and probably down the hierarchy.

Secondly, results of descriptive statistics also revealed that, all the dimensions of psychological empowerment positively influence human resource stability in diverse intensities. The Meaning dimension (PM) had a significant and positive influence on human resource stability, and was maximally provided (all 5 factors above threshold, M>3.45). Competence dimension (PC) had an insignificant but positive influence but was maximally provided (all 5 factors above threshold). Self-determination dimension (SD) had an insignificant but positive influence and moderately provided (4 factors above threshold). Impact dimension (IM) had the second highest significant and positive influence, but was largely not provided or largely absent (only 2 factors above threshold).

Thirdly, the results of descriptive statistics revealed that, human resource stability was found to be low (only 2 out of 7 factors agreement above threshold). Therefore, since the human resource stability was found to be low, the research concludes that the low human resource stability was largely caused by the absence of the impact cognition among middle level managers. Therefore, middle level managers in three and five star hotels did not perceive that they were making sufficient impact in their departments and organizations. It is therefore sufficient to conclude that, this adversely affected their commitment, job satisfaction, professional ego and self-esteem. Consequently, a critical number of them showed propensity to leave their organizations, adversely affecting human resource stability. Middle level managers should be made to feel that they can influence strategic, administrative and operating outcomes of work in their departments and the larger organizational matters for them to feel the impact they make in the organization, and promote human resource stability. Organizational values and practices should also respect employee's values and beliefs to foster perception of organizational meaningfulness among them. This is in agreement with the literature and the conclusion 
that, the empowered should feel a sense of personal worth with the ability to achieve outcomes. They should also have the power to make a difference or have impact on the organization, to perceive meaning in their jobs and organizations (Johnson, 1993; van Oudshoon\& Thomas, 1993; Thomas \& Velthouse, 1990); Stander \& van Zyl, 2015). Lashley (2002) sums it up that, psychological empowerment as a motivational aspect of empowerment becomes the defining feature of the initiatives and stability in hospitality organizations.

In summary, based on the inferential findings (correlations and regression findings), this study established that, there is a very significant and positive influence of psychological empowerment on human resource stability. Although some dimensions of psychological empowerment have stronger influence than others, they cannot be applied separately. Based on the foregoing, this research makes the following recommendations.

\section{Recommendations}

Based on the finding of the study the following recommendations are made:

- Top managements of three and five star hotels should actively evaluate the levels of psychological empowerment among their middle level managers with a view to create suitable empowerment programs, which will improve their psychological empowerment in the work places. Of particular concern in this respect are the meaning and impact dimensions, which specifically appeal to the self-esteem level of middle level managers.

- Top management should also pay attention to giving their middle-level managers more freedom to make decisions in their departments, as well as making more information about the company's mission and performance more available to more middle level managers, through as many channels as they are available. This will create a sense of self-determination and meaning or purpose as well as enhancing middle level manager's ability to make and influence decisions that are appropriately aligned with organizational goals and mission.

- Top level managers should device and implement reward and recognition systems which recognizes individual middle level manager's contribution so as to enhance perception of impact, as well as providing incentives for participating in, and effecting decision making processes at work so as to reinforce their locus of control

- Top management of three and five star hotels should actively engage middle level managers more to understand individual values and beliefs to fortify meaningfulness and locus of control. This will enable organizations to align their values, policies and practices accordingly and go a long way into promoting work engagement and stability on the job.

In addition, the following are the recommendations for further study

- Since this study was limited to three and five star hotels in Nairobi only, future studies may consider separate research for separate star ratings to establish whether psychological empowerment effects typical of each star rating has different impacts on human resource stability in those organizations.

- In addition, future studies may consider research further afield covering regions outside Nairobi to establish how different environments impact on the relationship between psychological empowerment and human resource stability.

- Lastly, the study was also limited to middle level management cadre in hotels. It is suggested that other studies may consider research on lower cadre staff and top management of hotels in this subject.

\section{Limitations of the Study}

There were a number of limitations, which may have affected this study. Classified hotels are busy establishments, therefore, securing appointments and accessing sources of data was a pervasive challenge. Although most of hotels responded to requests to participate in the research, one of the five star hotels declined participation citing company policy not to participate in external research studies. Time was another challenge the researcher had to contend. Often times, data collection was painfully slow owing to the respondent's tight schedules at work. The researcher had to make several trips and appointments to the participating properties in order to secure sufficient data for the study. Secondly, this research was self-funded, and balancing expenditure was constantly marred with uncertainties. The researcher often found himself in a gridlock of contingencies to provide for to carry the process forward successfully.

\section{References}

i. Alagaraja, M. (2013).Mobilizing organizational alignment through strategic human resource development.Human Resource Development International, 16(1), 74-93.

ii. Ambad, S. N. A., \& Bahron, A. (2012). Psychological empowerment: The influence on organizational commitment among employees in the construction sector. Journal of Global Business Management, 8(2), 73.

iii. Ashforth, B. E. (1989). The experience of powerlessness in organizations.Organizational behavior and human decision processes, 43(2), 207-242.

iv. Bandura, A. (1989). Human agency in social cognitive theory.American psychologist, 44(9), 1175.

v. Bryant, J. (2018). Hiring wisdom: Checking Stability Index-Enterprise talent acquisition:

vi. are.net/ SD. San Diego.

vii. Buitendach, J. H., \& Hlalele, R. B. T. (2015). Psychological empowerment and job satisfaction of engineers in a petrochemical industry: management. South African Journal of Economic and Management Sciences, 8(2), 154170.

viii. Chipunza, D. \& Barry, M. D., (2010). The relationship among survivor quality-attitude, commitment and motivation-after downsizing. African Journal of Business Management, 4(5), 604-613 
ix. Cooper, D. R., \& Schindler, P.S., (2011) Qualitative research.Business Research Methods, 160-182

x. Conger, J. A., \& Kanungo, R. N. (1988). The empowerment process: Integrating theory and practice. Academy of management review, 13(3), 471-482.

xi. Das, B. L., \& Baruah, M., (2013). Employee retention: a review of literature, Journal of Business Management, $14(2), 8-16$

xii. Davidson, M. C. G., Timo, N. \& Wang, Y. (2010). How much does labour turnover cost? A case study of Australian four- and five-star hotels. International Journal of contemporary hospitality management. 22(4)451-466.

xiii. Deci, E. L., Connell, J. P., \& Ryan, R. M. (1989).Self-determination in a work organization.Journal of applied psychology, 74(4), 580.

xiv. Deloitte Consulting (Pty), (2014). Kenya human capital trends 2014: Engaging the 21st Century Workforce. Nairobi, Kenya. Deloitte Pty.

xv. Development Dimension International, (2013). Retrieved August 05, 2018fromhttp:/ / www.ddiworld.com.

xvi. Fourie, A. S., \& Van Eeden, R. (2010).The conceptualization of psychological empowerment in a South African work context. South African Journal of Labour Relations, 34(1), 7-30.

xvii. Iftikhar, M., Shahid, M., Shahab, M., Mobeen, M. \&Kureshi, M. (2016) Exploring the relationship among organizational citizenship behavior, psychological empowerment and turnover intentions with a mediating role of effective commitment. International Journal of Management and Marketing, 6(S4), 296-304.

xviii. Hinking, T. R. \& Tracy, J. B. (2000).The cost of turnover.Putting a price on the learning curve.Cornell Hotel \& Restaurant Administration Quarterly, 4(3), 14-21

xix. IBM Corporation, (2016). IBM SPSS Statistics for windows, version 22.0. Armok, NY: IBM Corp

xx. ILO (2010). Challenges for global hospitality industry: an HR perspective. Hospitality and Tourism Themes,4(2), 150-162

xxi. Ikechuku, O. \& Thandokazi, L. (2017). Length of service Vs employee retention factors: Hotels in Cape Town, South Africa. ActaUniversitatDanubius, 13(2) 5-16.

xxii. Kabare, K., Maina, M. \& Gachuga, H. (2016) Influence of psychological empowerment on organizational commitment in Kenya civil service.The Strategic Journal of Business and Change Management, 3(6), 183-146.

xxiii. Kanter, R. M. (1993). Men and Women of the corporation (2nded,). New York, NY: Basic Books.

xxiv. Kothari, C. R. (2004). Research methodology: Methods and techniques (2nd Ed). Jaipur, India: New Age International.

xxv. Kuria, S., Odigi, A. \& Wanderi, P. M., (2012).Assessment of causes of labour turnover in three and five star-rated hotels in Kenya.International journal of business and social science, 3(15).

xxvi. Kuria, S., (2011). Factors influencing labour turnover in three and five star-rated hotels in Nairobi, Kenya. International Journal of Humanities and Social Science, 1(20), 195-201.

xxvii. Lashley, C., (2002). Empowerment: HR Strategies for Service Excellence. Oxford, MA: Butterworth-Heinemann .

xxviii. Lore, J. (2017). 8 Essential employee retention factors modern employers ignore. (ORise-E book), www.risepeople.com. Retrieved on 09/07/ 18

xxix. Maslow, A. (1970). Motivation and personality (2nd Ed) New York, NY: Harper.

xxx. Menon, S.(2001). Employee empowerment: An integrative psychological approach. Applied Psychology, 50(1),153-180.

xxxi. Mugenda, O. \& Mugenda A. (2003). Research methods: quantitative and qualitative approaches.

xxxii. Munjavacas, A. S. \& Iborra, C. M., (2014).Internal employability as a strategy for key employee retention.RevistaInnova Journal, 24(53), 1-22

xxxiii. Nawawi, W., Hussain, F., Ramli, N., Sulaiman, W. \& Rzali, N. (2015). Psychological empowerment influence on retention intentions of five star rated Spas' employees. Journal of Applied Environmental andBiological Sciences. (5), 95-99.

xxxiv. Pelit, E., Ozturk, E., \& Arslanturk, Y., (2017). Effects of employee empowerment on job satisfaction: A study of hotels in Turkey. Ganzi University Depository-Golbasi, Ankara. Turkey. www .emerald/ 559-6119.htm

xxxv. PWC. (20I6). Rooms with an African touch: Hotels outlook 2016 - 2020, South Africa, Nigeria, Mauritius, Kenya and Tanzania. Retrieved from www.pwc.co.za/ hospitality-and-leisure

xxxvi. Ramos, A. \& Ales, Y. (2014). Empowering employees: structural empowerment as antecendent of job satisfaction in university settings. Clinical and experimental psychology, Hueva University, Hueva, Spain. Open journal, 7(1), 28-36

xxxvii. Ryan, R. M., \& Deci, E. L. (2000).Self-determination theory and the feeling of intrinsic motivation, social development and well-being. American Psychologist, 55(1),6

xxxviii. Spreitzer, G. M. (1995). Psychological empowerment in the workplace. Academy of Management Journal, 38(5) $1442-1465$.

xxxix. Spreitzer, G. M. (1996). Social structural characteristics of psychological empowerment. Academy ofmanagement journal, 39(2), 483-504.

xl. Spreitzer, G. M., \& Mishra, A. K. (1999). Giving up control without losing control: Trust and it substitutes' effects on managers' involving employees in decision-making. Group \& Organization Management, 24(2), 155-187.

xli. Spreitzer, G. M., De Janasz, S. C., \& Quinn, R. E. (1999).Empowered to lead: The role of psychological empowerment in leadership. Journal of Organizational Behavior, (20) 511-526. 
xlii. Stander, M. \& van Zyl, E. (2015). Leadership empowering behavior, psychological empowerment, organizational citizenship behaviors and turnover intention in a manufacturing company.Journal of Industrial Psychology, 41(1), $1-14$

xliii. Stander, M. W. \& de Clerk, S. (2014). Investigation of leadership empowerment behavior, psychological empowerment, work engagement and turnover intention: The role of psychological empowerment. Journal of Positive Management, 5(3), 28-45

xliv. Stander, W., Nel, T. \& Latif, J. (2015).Investigating positive leadership, psychological empowerment, work engagement and satisfaction with life in a chemical industry.South African Journal of Industrial Psychology, 41(2), $1-13$.

xlv. Tavakol, T \& Dennick, R. (2011).Making Sense of Cronbach's Alpha. International Journal of Medical Education, 2910, 53-

xlvi. Thomas, K. W., \& Velthouse, B. A. (1990). Cognitive elements of empowerment: An "interpretive" model of intrinsic task motivation. Academy of management review, 15(4), 666-681. 